Article

\title{
Herbal Tea for the Management of Pharyngitis: Inhibition of Streptococcus pyogenes Growth and Biofilm Formation by Herbal Infusions
}

\author{
Niluni M. Wijesundara ${ }^{1,2}$ and H. P. Vasantha Rupasinghe ${ }^{3,4, * \text { (D) }}$ \\ Department of Biology, Faculty of Science, Dalhousie University, Halifax, NS 3H 4R2, Canada \\ 2 Department of Animal Science, Faculty of Animal Science and Export Agriculture, Uva Wellassa University, \\ Badulla 90 000, Sri Lanka \\ 3 Department of Plant, Food, and Environmental Sciences, Faculty of Agriculture, Dalhousie University, Truro, \\ NS B2N 5E3, Canada \\ 4 Department of Pathology, Faculty of Medicine, Dalhousie University, Halifax, NS B3H 4R2, Canada \\ * Correspondence: vrupasinghe@dal.ca; Tel.: +1-902-893-6623; Fax: +1-902-893-1404
}

Received: 4 August 2019; Accepted: 23 August 2019; Published: 24 August 2019

check for updates

\begin{abstract}
Herbal teas are becoming popular as functional beverages due to their various health promotional properties. This study aimed at assessing 13 hot water infusions (HWIs) from different herbs against streptococcal pharyngitis (strep throat). Licorice root exhibited the lowest minimum inhibitory concentrations (MIC) of $1.56 \mathrm{mg} / \mathrm{mL}$, followed by barberry root, thyme, and oregano flowering shoots, with a MIC of $3.13 \mathrm{mg} / \mathrm{mL}$. At their respective minimum bactericidal concentrations (MBC), licorice showed the bactericidal effect on S. pyogenes within $12 \mathrm{~h}$ after exposure while others need $24 \mathrm{~h}$ for a similar outcome. The HWIs exhibited inhibitory activity on biofilm formation, ranging from 1.56 to $6.25 \mathrm{mg} / \mathrm{mL}$, which confirmed by ruptured cells or clusters of dead cell debris observed in scanning electron microscope (SEM). Overall, non-toxic concentrations of efficacious HWIs from licorice root, barberry root, thyme, and oregano flowering shoots may provide potential sources for developing herbal teas or biomedicine for the management of $S$. pyogenes infections.
\end{abstract}

Keywords: herbal plants; hot water infusions; phytochemicals; natural health product; Streptococcus pyogenes; mass spectrometry

\section{Introduction}

For centuries, the therapeutic properties of various spices and herbal plants have been used to treat several bacterial infections. Streptococcal pharyngitis (strep throat), an acute infection of the nasopharynx and oropharynx, is one of the common upper respiratory infections, primarily caused by Streptococcus pyogenes. It accounts for more than $37 \%$ of all diagnosed sore throat cases in children and up to $5-10 \%$ in adults reports millions of cases per year worldwide [1,2].

Investigation of natural antimicrobial agents as alternatives to synthetic counterparts have received significant attention from researchers and natural health product industry. Therefore, plant-derived new natural antimicrobial agents have been explored against various infectious bacteria, including S. pyogenes. It has been presumed that herbal remedies and formulations are moderately efficacious but safer from side effects in contrast to most pharmaceutical agents [3]. A World Health Organization survey reported that around $70-80 \%$ of the world population use herbal remedies as their primary health care [4]. Usage of complementary and alternative therapies in Canada has increased at an exponentially growing pace in recent years, and the estimated use of alternative or herbal remedies in place of conventional medicine is nearly $30 \%$ of the total population in the United States [5]. 
The use of herbal plants for various medicinal purposes by traditional healers in North America has been reported. Interestingly, over 2500 species of plants have been used by both Native Americans and Americans of European origin in their traditional medicine systems [6]. The First Nations have used the fresh plant parts or their extracts of herbal plants such as slippery elm, sage, barberry, oregano, thyme, licorice, and echinacea, and Canadian folk remedial applies for sore throat conditions. Based on the plant used, type of infection, and the situations of the patient is being treated the preparation of herbal remedies are different such as infusions (hot teas), decoctions (boiled teas), macerations (cold-soaking), or tinctures (solvent/water extracts and distillations) [7].

The rapidly expanding natural health product industries keep introducing new herbal supplements, functional food, and herbs-based energy drinks led by the increased demand for the use of medicinal remedies from consumers. Drinking herbal tea is gaining popularity as one of the most pleasurable beverages as well as an efficient herbal remedy due to its health promotional properties. Herbal teas have been identified and approved as a natural and nonprescription drug in some countries, including Canada, as a remedy for oral and pharyngeal mucosal irritations with a dry cough.

Due to the potential side effects of long-term administration of traditional herbal medicines for the management of streptococcal pharyngitis, it is necessary to have proper clinical laboratory investigations on their activity and safety compared with synthetic antibiotics. However, hot water infusions (HWIs) of selected plant parts of the current study (Table 1) have not been reported or limited with emphasizing both growth and biofilm inhibition of S. pyogenes. Therefore, this study aimed to identify the potential herbals with antibacterial activity and antibiofilm efficacy of 13 HWIs from different parts of herbal plants against three S. pyogenes strains, to develop specialty herbal tea for relieving pain and other complications due to streptococcal pharyngitis.

\section{Materials and Methods}

\subsection{Chemicals and Reagents}

3-(4, 5-Dimethylthiazol-2-yl)-2, 5-diphenyltetrazolium bromide (MTT) was purchased from Life Technologies (Burlington, ON, Canada). Bacteriological agar and brain heart infusion (BHI) media were purchased from Oxoid Ltd. (Nepean, ON, Canada). Dimethyl sulfoxide (DMSO), penicillin G sodium salt, phosphate-buffered saline (PBS), sodium chloride ( $\geq 99.0 \%$, ACS reagent), and other chemicals were obtained from Sigma-Aldrich (Oakville, ON, Canada).

\subsection{Collection of Plant Materials}

Eleven different medicinal plants which were commonly used in the Canadian indigenous medicine were considered in the present study. Their common names, scientific names, and specific parts used are summerized in Table 1 were selected. Geranium (Voucher No: 13010), Sage (Voucher No: 13011), oregano (Voucher No: 13012), and thyme (Voucher No: 13013) were collected from the university's herbal garden, Faculty of Agriculture, Dalhousie University, at GPS location of $45^{\circ} 22^{\prime} 23.3^{\prime \prime} \mathrm{N}$ and $63^{\circ} 15^{\prime} 45.2^{\prime \prime} \mathrm{W}$ during flowering period. Purple coneflower/Echinacea (Voucher No: 13009), was collected at GPS location of $45^{\circ} 22^{\prime} 20.8^{\prime \prime} \mathrm{N}$ and $63^{\circ} 15^{\prime} 43.8^{\prime \prime} \mathrm{W}$. A taxonomist was authenticated the herbal plants and specimens were deposited in the A.E. Roland herbarium, Department of Plant, Food, Environmental Sciences, Faculty of Agriculture, Dalhousie University, Canada. Canadian ginger and clove flower buds were purchased from the local and supermarket. Fresh plant parts were washed, cut into small pieces, and dried at $50{ }^{\circ} \mathrm{C}$. Ground powders were stored at $-80{ }^{\circ} \mathrm{C}$ in airtight containers. Barberry root, slippery elm inner bark, licorice root, and olive leaves were obtained as a powder from Mother Earth Natural Health Inc. (Ottawa, ON, Canada).

\subsection{Preparation of Hot Water Infusions (HWIs)}

Dried powder of herbal plant parts was infused with distilled water in 1:10 $(w / v)$ ration in a boiling water bath (ISOTEMP-205, Fisher Scientific, Ottawa, ON, Canada) for $10 \mathrm{~min}$. After infusion period, 
mixtures were filtered. Filtrates were frozen overnight and freeze dried at $-20^{\circ} \mathrm{C}$ using a freeze dryer (Kinetics, FTS Systems Inc., Stone Ridge, NY, USA) for 24-48 h. The dried samples were scraped out and were stored in labeled sterile screw-capped amber bottles, in the freezer at $-80{ }^{\circ} \mathrm{C}$ until used for further analysis.

\subsection{Characterization of Phytochemicals in HWIs}

\subsubsection{Determination of Total Phenolic and Total Carotenoids Contents}

The total phenolic contents and total carotenoids content were assessed for all the HWIs, and results were previously published by authors [8].

\subsubsection{Characterization of Phytochemical Profile}

Potential phytochemicals present in HWIs were characterized using ultra-performance liquid chromatographic-electrospray ionization-tandem mass spectrometry (UPLC-ESI-MS/MS) as described in our previous study [9]. Briefly, UPLC was directly interfaced with a High Definition MS System (Waters Xevo TQ-Smicro, Waters Corporation, Milford, USA) with an electrospray ionization (ESI) source operating in negative ion mode with ionization conditions of capillary voltage of $2.0 \mathrm{~V}$, sampling cone voltage of $25.0 \mathrm{~V}$ and extraction cone voltage of $3.5 \mathrm{~V}$. The optimal temperatures $\left(150{ }^{\circ} \mathrm{C}\right.$ of source temperature and $450{ }^{\circ} \mathrm{C}$ of desolvation gas temperature) and optimal gas flows (100 L/h of cone gas flow and $1000 \mathrm{~L} / \mathrm{h}$ of desolvation gas flow) were maintained. Full-scan mass acquisitions in negative ion mode were made by scanning the $m / z$ range of 100-1100 Da. Data were collected in centroid mode. Masses were corrected using an external reference (Lock-Spray ${ }^{\mathrm{TM}}$ ) comprising a $\mathrm{C}_{18}$ column (UPLC ${ }^{\circledR} \mathrm{BEH} \mathrm{C}_{18}$, Waters Corporation, USA). The filtered samples were auto injected into the column. A mixture of $0.1 \%$ formic acid in water (solvent $\mathrm{A}$ ) and $0.1 \%$ formic acid in acetonitrile (Solvent $\mathrm{B}$ ) was used as the mobile phase. The total run time was $12 \mathrm{~min}(2 \mathrm{~min}(83.5 \% \mathrm{~A}), 2.6 \mathrm{~min}(83.0 \% \mathrm{~A})$, $3.1 \mathrm{~min}(82.5 \% \mathrm{~A}), 4 \mathrm{~min}(81.5 \% \mathrm{~A}), 4.7 \mathrm{~min}(80.0 \% \mathrm{~A}), 6.6 \mathrm{~min}(20.0 \% \mathrm{~A}), 8.2 \mathrm{~min}(20.0 \% \mathrm{~A})$, and $12 \mathrm{~min}$ $(94.0 \%)$ ), with $94.0 \%$ of solvent A flow of $0.3 \mathrm{~mL} / \mathrm{min}$. The deprotonated $\left(\mathrm{M}-\mathrm{H}^{+}\right)^{-}$ions identified using the full scan mode was used to generate selected ion monitoring (SIM) channels (51 channels). The samples were run in SIM mode to confirm the abundance of each recognized compounds matching to their retention times of SIM mode and full scan mode. These identified phytochemicals were confirmed with the existing literature (Table 1).

\subsection{Bacteria and Growth Conditions}

Two American Type Culture Collection (ATCC) of S. pyogenes (ATCC 19615 and ATCC 49399), as well as a pharyngeal isolate from a streptococcal pharyngitis patient (Queen Elizabeth II Health Sciences Centre, Halifax, NS, Canada) were used.

Following the manufacturer's instructions, inoculums were prepared and stored at $-80{ }^{\circ} \mathrm{C}$ in $1: 1$ $(v / v)$ of brain heart infusion (BHI) broth: $40 \%$ glycerol. Strains were cultured on BHI agar plates, were maintained for seven days at $37^{\circ} \mathrm{C}$. For experiments, a few colonies were inoculated in BHI broth, were incubated at $37^{\circ} \mathrm{C}$ for about $16 \mathrm{~h}$ and standardized with saline water $(0.85 \% \mathrm{NaCl}, \mathrm{pH}=7.0 \pm$ 0.1 ) according to the previously reported method [10].

\subsection{Anti-Bacterial Activity}

\subsubsection{Screening for Inhibitory Antibacterial Effects of HWIs}

The spot-on-the-lawn method was used for initial screening to verify the antibacterial effects of HWIs, with ATCC 19615 and ATCC 49399 bacterial cultures. The samples were spotted, plates were incubated at $37^{\circ} \mathrm{C}$ for $24-48 \mathrm{~h}$ and examined for the zone of inhibitions. 


\subsubsection{Determination of Minimum Inhibitory Concentrations (MICs)}

Effect of HWIs on bacterial growth was assessed using the standard micro broth-dilution method recommended by the Clinical and Laboratory Standards Institute [11]. Briefly, $100 \mu \mathrm{L}$ volumes of diluted bacterial suspensions $\left(10^{6} \mathrm{CFU} / \mathrm{mL}\right)$ in $\mathrm{BHI}$ broth were incubated with the same amount of serial two-fold diluted HWIs ( 0.2 to $50 \mathrm{mg} / \mathrm{mL})$, penicillin $\mathrm{G}\left(4.0 \times 10^{-4}\right.$ to $\left.0.5 \mu \mathrm{g} / \mathrm{mL}\right)$, and BHI media (diluent control). The assay was carried out in 96 -well microplate, and bacteria growth was measured as absorbance at OD $600 \mathrm{~nm}$ after $24 \mathrm{~h}$ incubation $\left(37^{\circ} \mathrm{C}\right)$. The MIC values corresponded to the lowest concentration of test compounds that inhibiting visible bacterial growth or showing a significant change of absorbance compared to the growth of control (in the spectrophotometric method) were recorded.

\subsubsection{Determination of Minimum Bactericidal Concentrations (MBCs)}

MBCs were determined by subculturing $15 \mu \mathrm{L}$ from non-turbid wells on BHI agar plate, and colony growth was observed after $24 \mathrm{~h}$ incubation at $\left(37^{\circ} \mathrm{C}\right)$. The $\mathrm{MBC}$ value is the lowest concentration where no visible colony growth was observed, compared to the control.

\subsubsection{Time-Kill Curves}

The time taken to show a bactericidal activity by HWIs was measured using time-kill curves as a previously described method [10]. Briefly, the bacterial count was enumerated in $3 \mathrm{~h}$ intervals over 24 $\mathrm{h}$ incubation periods at $37^{\circ} \mathrm{C}$ with different concentrations of licorice root, oregano flowering shoot, thyme flowering shoot HWIs (their own $1 / 2 \times \mathrm{MIC}$, MIC, and $2 \times \mathrm{MIC}$ ). BHI media alone with bacteria was used as a diluent control, and penicillin $\mathrm{G}$ was as the positive control. The assays were performed in triplicate, and the results were expressed as $\log \mathrm{CFU} / \mathrm{mL}$.

\subsection{Anti-Biofilm Formation Activity}

2.7.1. Determination of Minimum Biofilm Inhibitory Concentrations (MBIC) and Biofilm Quantification by MTT Assay

The effect of HWIs on biofilm formation of $S$. pyogenes was examined using a 3-[4-dimethyl-2-thiazolyl]-2, 5-diphenyl-2H-tetrazolium-bromide (MTT) assay as described previously [10]. As in the MIC assay, two-fold serial dilutions of four HWIs and penicillin G were prepared in 96-well plates and were inoculated with $100 \mu \mathrm{L}$ of $1 \times 10^{6} \mathrm{CFU} / \mathrm{mL}$ bacterial suspensions. After three days of incubation at $37^{\circ} \mathrm{C}$, the plates were emptied by flipping them over to remove the planktonic bacteria. Fresh BHI broth $(100 \mu \mathrm{L})$ supplemented with $10 \mu \mathrm{L}$ of $12 \mathrm{mM}$ MTT was then added into each well, followed by incubation for $3 \mathrm{~h}$ at $37^{\circ} \mathrm{C}$. DMSO $(50 \mu \mathrm{L})$ was added after the careful removal of $85 \mu \mathrm{L}$ of BHI broth from each well. Biofilm formation was calorimetrically quantified by measuring reduction ability of tetrazolium salt (yellow) into a formazan (purple) by the activity of dehydrogenase enzymes in surviving bacteria in biofilms. Absorbance at $540 \mathrm{~nm}$ was measured using a microplate reader (EpochTM, Biotek, Winooski, VT, USA). Percentage inhibitions were calculated as follows: $\left[1-\left(\mathrm{A}_{540}\right.\right.$ Treatment $\left.\left./ \mathrm{A}_{540} \mathrm{Control}\right)\right] \times 100$. The minimum biofilm inhibition concentration (MBIC) was defined as the lowest concentration.

\subsubsection{SEM Visualization of Biofilms}

To examine the effects of selected HWIs on morphology, treated bacterial cells with HWIs at their respective sub-MIBCs were fixed as described in Wijesundara and Rupasinghe [10]. Briefly, treated cells were centrifuged, washed with PBS, and fixed in $0.1 \mathrm{M}$ sodium cacodylate buffer ( $\mathrm{pH}$ 7.2) containing $2 \%$ glutaraldehyde $(2 \mathrm{~h})$ and then in $4 \%$ osmium tetroxide $(4 \mathrm{~h})$. Biofilms were then dehydrated using gradient series of ethanol (35\%; 50\%; 75\%; 90\%; 100\%) and hexamethyldisilazane/ethanol gradient series $(25: 75 ; 50: 50 ; 75: 25 ; 100: 0 \%)$. The samples were air-dried for $2 \mathrm{~h}$ under the fume hood and were mounted on aluminum sputters. Then, sputters were coated with gold-palladium $(15 \mathrm{~nm})$ and were visualized under SEM (Hitachi FEG-SEM 4700, Hitachi Ltd., Tokyo, Japan) using operational 
conditions of 10 kilovolts $(\mathrm{kV})$ of acceleration voltage, 14-16 microamps $(\mu \mathrm{A})$ of emission current, 10-12 mm working distance and the analysis lens mode. Micrographs were captured at different magnifications. The experiment was performed in triplicates for three independent times.

\subsection{Statistical Analysis}

The complete randomized design was used, and all the experiments were performed in triplicates and three independent times. One-way analysis of variance (ANOVA) was performed using Minitab statistical software (Version 17.0, Minitab Inc., State College, PA, USA). Tukey's test was used to determine the differences among treatments, and significant differences were defined as $p<0.05$, and the results were expressed as the mean \pm standard deviation. The time to kill curves were plotted using GraphPad Prism version 5.0 for Windows (GraphPad Software, La Jolla, CA, USA).

\section{Results}

\subsection{Characterization of HWIs Using UPLC-ESI-MS/MS}

We have previously reported the total phenolic content, and total carotenoid content of these HWIs [8]. Potential phytochemicals found in HWIs expressed with their deprotonated molecular mass and retention time $\left(\left(\mathrm{M}-\mathrm{H}^{+}\right)^{-}, \mathrm{RT}\right)$ were summarized in Table 1. The full-scan mode total ion chromatograms, SIM scan channels, mass spectrum, and molecular structure of the selected major phytochemicals identified by UPLC-ESI-MS/MS of most effective HWI, licorice root, are presented in Figure 1. Furthermore, UPLC-ESI-MS/MS identification results of barberry root, oregano flowering shoots, and thyme flowering shoots are included in supplementary figures section (Figures S1-S3). 
Table 1. Potential phytochemical profile of the selected herbal plant parts.

\begin{tabular}{|c|c|c|c|c|c|}
\hline \multicolumn{2}{|c|}{ Plant Name } & \multirow{2}{*}{ Family } & \multirow{2}{*}{ Parts Used } & \multirow{2}{*}{$\begin{array}{l}\text { Potential Major Phytochemicals } \\
\qquad\left(\left(\mathrm{M}-\mathrm{H}^{+}\right)^{-}, \mathrm{RT} \text { in } \mathrm{min}\right)\end{array}$} & \multirow{2}{*}{ References } \\
\hline Common & Botanical & & & & \\
\hline Barberry & Berberis vulgaris $\mathrm{L}$. & Berberidaceae & Roots & $\begin{array}{c}\text { Gingerol }(293.38,8.06), \text { Caffeic acid }(179.16,3.22) \text {, } \\
\text { Naringin }(579.54,5.99) \text {, Naringenin }(271.26,7.32) \text {, and } \\
\text { Rosmerinic acid }(359.32,2.01) .\end{array}$ & [12] \\
\hline Clove & Syzygium aromaticum $\mathrm{L}$. & Myrtaceae & Flower buds & $\begin{array}{c}\text { Eugenol }(163.20,4.40) \text {, Eugenyl acetate }(205.24,8.43) \text {, and } \\
\beta \text {-Ocimene }(135.25,4.25) .\end{array}$ & [13-15] \\
\hline \multirow[t]{3}{*}{ Echinacea } & \multirow[t]{3}{*}{ Echinacea purpurea L. } & \multirow[t]{3}{*}{ Asteraceae } & Flowers & $\begin{array}{c}\text { Caftaric acid }(311.23,2.44), \text { Chlorogenic acid }(353.31,2.78), \\
\text { Caffeic acid }(179.16,3.27), \text { Cynarin }(515.46,6.02), \\
\text { Echinacoside }(785.73,6.56) \text {, Cichoric acid }(473.37,4.78), \\
\text { and } \beta \text {-Sitosterol }(413.70,4.61) .\end{array}$ & \multirow[t]{3}{*}{ [16-19] } \\
\hline & & & Stems & Quercetin $(301.23,6.12)$ and Eugenyl acetate $(205.24,8.43)$. & \\
\hline & & & Leaves & $\begin{array}{c}\text { Caftaric acid }(311.23,2.44), \text { Cichoric acid }(473.37,4.78), \\
\text { and Caffeic acid }(179.16,3.27) .\end{array}$ & \\
\hline Ginger & Zingiber officinale $\mathrm{L}$. & Zingiberaceae & Rhizomes & $\begin{array}{c}\text { Gingerol }(273.38,7.18), \alpha \text {-Humulene }(203.24,2.50) \text {, } \\
\text { Gingerol }(293.38,7.18), \alpha \text {-Thujone/ } \beta \text {-Thujone/camphor } \\
(151.23,4.35), \alpha \text { or } \beta \text {-Caryophyllene }(203.35,2.52), \text { Caffetic } \\
\text { acid }(311.23,10.07) \text {, and Liquirtin }(419.39,6.21) .\end{array}$ & {$[20,21]$} \\
\hline Licorice & Glycyrrhiza glabra L. & Papilionaceae & Roots & $\begin{array}{c}\text { Glycyrrhizin }(821.94,6.86), \text { Glabridin }(323.97,7.54) \text {, } \\
\text { Thymohydroquinone }(165.22,2.81) \text {, Naringenin }(271.26 \text {, } \\
\text { 7.32), Asparegene }(131.12,1.63), \text { Liquirtin }(417.39,6.34), 5 \\
\text {-Methoxyhydnocarpin }(493.45,6.28) \text {, Cynarin }(515.46, \\
\text { 6.02), Quercetin }(301.23,6.12), \text { p-Cyemene }(133.21,0.82) \text {, } \\
\text { Generdiol (153.23, 3.47), } \alpha \text {-Humulene }(203.35,2.53) \text {, and } \\
\text { Kaempferol }(285.23,6.42) .\end{array}$ & {$[22,23]$} \\
\hline Oregano & Origanum vulgare $\mathrm{L}$. & Lamiaceae & Flowering shoots & $\begin{array}{c}\text { Rosmerinic acid (359.32, 6.20), Oleanolic acid (455.71, } \\
\text { 7.23), } \rho \text {-Cymene }(133.21,1.04), \text { and } \\
\text { 5-Methoxyhydnocarpin }(493.45,6.25)\end{array}$ & {$[24,25]$} \\
\hline Olive & Olea europeus L. & Oleaceae & Leaves & $\begin{array}{l}\text { Hydroxytyrosol, Rutin, Luteolin-7-glucoside, Oleuropein } \\
\text { glucoside, Luteolin- } 4^{\prime} \text {-glucoside, Oleuropein, and } \\
\text { Oleuropein aglycon. }\end{array}$ & [26-28] \\
\hline Rose geranium & Pelargonium graveolens L. & Geraniaceae & Leaves & Geraniol $(151.24,6.62)$ & [29] \\
\hline
\end{tabular}


Table 1. Cont.

\begin{tabular}{|c|c|c|c|c|c|}
\hline \multicolumn{2}{|c|}{ Plant Name } & \multirow{2}{*}{ Family } & \multirow{2}{*}{ Parts Used } & \multirow{2}{*}{$\begin{array}{l}\text { Potential Major Phytochemicals } \\
\left(\left(\mathrm{M}-\mathrm{H}^{+}\right)^{-}, \mathrm{RT} \text { in } \mathrm{min}\right)\end{array}$} & \multirow{2}{*}{ References } \\
\hline Common & Botanical & & & & \\
\hline Sage & Salvia officinalis L. & Lamiaceae & Leaves & $\begin{array}{c}\text { 1,8-Cineole (153.24, } 2.18 \text { Borneol and/or Linalool and/or } \\
\alpha \text {-Terpineol and/or } \beta \text {-Pinene (153.24, 4.01), } \beta \text {-carotene } \\
\text { (535.87, 3.46), } \gamma \text {-Terpinene and/or Mycrene and/or } \\
\beta \text {-Pinene and/or } \alpha \text {-Pinene (135.24, 4.24), Asparegene } \\
(131.12,3.65), \text { and } \alpha \text {-Terpine }(135.24,4,42) .\end{array}$ & {$[25,30,31]$} \\
\hline Slippery elm & Ulmus rubra Muhl. & Ulmaceae & Inner barks & $\begin{array}{l}\text { Ursolic acid /Betulinic acid }(455.71,9.5) \text { and } \beta \text {-carotene } \\
\qquad(535.87,5.29)\end{array}$ & [32] \\
\hline Thyme & Thymus vulgaris $\mathrm{L}$. & Lamiaceae & Flowering shoots & $\begin{array}{c}\text { Thymol and Carvacrol }(149.21,6.65) \text {, } \\
\text { Thymohydroquinone }(165.22,7.17), \gamma \text {-Terpinene, } \\
\text { Myrcene, and } \alpha \text {-Pinene }(135.24,4.24), \text { Gingerol (293.38, } \\
\text { 7.68), and Kaempferol }(285.23,6.42)\end{array}$ & {$[25,33]$} \\
\hline
\end{tabular}




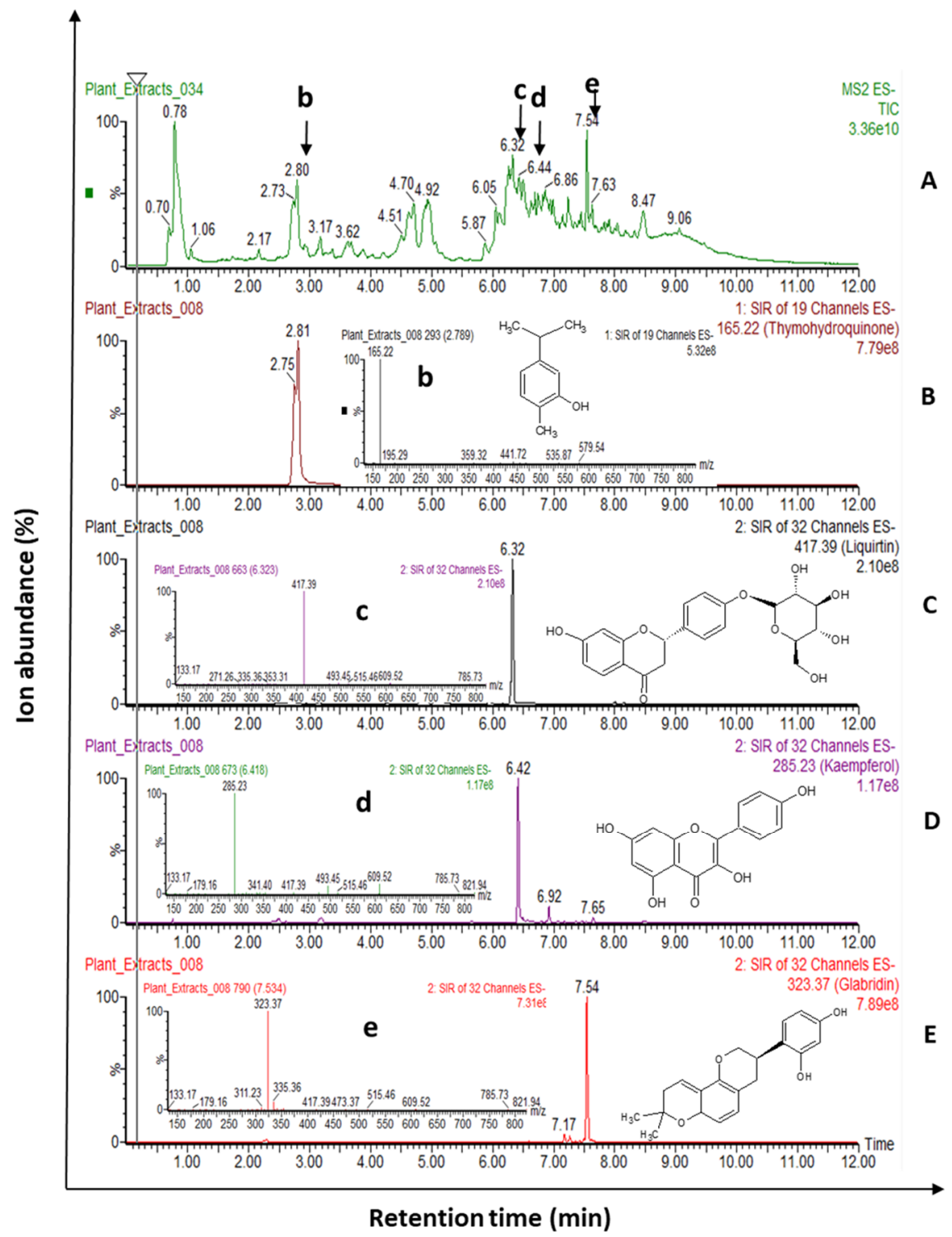

Figure 1. The full scan mode total ion chromatogram of licorice root hot water infusion from a negative mode of UPLC-ESI-MS/MS analysis (A). The SIM channels (B-E) and mass spectra of the full-scan of selected four major phytochemicals; thymohydroquinone (b), liquiritin (c), kaemferol (d), and glabridin (e) are shown for $m / z$ of deprotonated ions of 165.22, 417.39, 285.23, and 323.97, respectively. The identified phytochemical name and chemical structure are presented. SIM: Selective ion monitoring scan; TIC: Total ion chromatograms, UPLC-ESI-MS/MS: Ultra-performance liquid chromatographic-electrospray ionization-tandem mass spectrometry.

\subsection{HWIs Inhibits S.Pyogenes Planktonic Growth}

The antibacterial activities of 13 HWIs have assessed against three strains of S. pyogenes (ATCC 19615, ATCC 49399 and a clinical isolate) and MIC and MBC values shown in Table 2. Zone of inhibitions around the spotted HWIs were detected in the initial screening and shown in Figure 2A. The HWI of licorice root exhibited greater activity against S. pyogenes planktonic growth with the lowest MIC of $1.56 \mathrm{mg} / \mathrm{mL}$ followed by barberry root, thyme, and oregano flowering shoots, as indicated by the relatively lower MIC of $3.13 \mathrm{mg} / \mathrm{mL}$. Colony growth of sub-cultured four HWIs on BHI agar, which demonstrated significant distinct bactericidal effects shown in Figure 2B. 
Table 2. The minimum inhibitory concentration (MIC) and minimum bactericidal concentration (MBC) of hot water infusions against three strains of Streptococcus pyogenes. ATCC: American Type Culture Collection.

\begin{tabular}{|c|c|c|c|c|c|c|c|c|c|}
\hline \multirow{2}{*}{ Plant-Source, Plant Part } & \multicolumn{3}{|c|}{ ATCC 19615} & \multicolumn{3}{|c|}{ ATCC 49399} & \multicolumn{3}{|c|}{ Clinical Isolate } \\
\hline & $\mathrm{MIC}(\mathrm{mg} / \mathrm{mL})$ & $\mathrm{MBC}(\mathrm{mg} / \mathrm{mL})$ & MBC/MIC & $\mathrm{MIC}(\mathrm{mg} / \mathrm{mL})$ & $\mathrm{MBC}(\mathrm{mg} / \mathrm{mL})$ & MBC/MIC & $\mathrm{MIC}(\mathrm{mg} / \mathrm{mL})$ & MBC (mg/mL) & MBC/MIC \\
\hline Clove FB & 12.50 & 25.00 & 2 & 12.50 & 25.00 & 2 & 12.50 & 25.0 & 2 \\
\hline Sage L & 12.50 & 25.00 & & 12.50 & 25.00 & & 12.50 & 25.0 & \\
\hline Ginger-Canada Rh & 50.00 & $>50.00$ & - & 50.00 & $>50.00$ & - & NA & NA & - \\
\hline Ginger-Chinese Rh & 50.00 & $>50.00$ & - & 50.00 & $>50.00$ & - & NA & NA & - \\
\hline Oregano FB & 3.13 & 6.25 & 2 & 3.13 & 6.25 & 2 & 3.13 & 6.25 & 2 \\
\hline Thyme FB & 3.13 & 6.25 & 2 & 3.13 & 6.25 & 2 & 3.13 & 6.25 & 2 \\
\hline Licorice R & 1.56 & 3.13 & 2 & 1.56 & 3.13 & 4 & 3.13 & 6.25 & 2 \\
\hline Barberry R & 3.13 & 6.25 & 2 & 3.13 & 6.25 & 2 & 3.13 & 6.25 & 2 \\
\hline Echinacea L & 50.00 & $>50.00$ & - & 50.00 & $>50.00$ & - & NA & NA & - \\
\hline Echinacea S & 6.25 & 12.50 & 2 & 6.25 & 12.50 & 2 & 6.25 & 12.50 & 2 \\
\hline Echinacea F & 50.00 & $>50.00$ & - & 50.00 & $>50.00$ & - & 50.00 & $>50.00$ & - \\
\hline Geranium L & 25.00 & 50.00 & 2 & 25.00 & 50.00 & 2 & NA & NA & - \\
\hline Slippery elm IB & $>50.00$ & $>50.00$ & - & $>50.00$ & $>50.00$ & - & NA & NA & - \\
\hline Olive L & $>50.00$ & $>50.00$ & - & $>50.00$ & $>50.00$ & - & NA & NA & - \\
\hline Penicillin G & 0.0078 & 0.0156 & 2 & 0.0078 & 0.0156 & 2 & 0.0078 & 0.0156 & 2 \\
\hline
\end{tabular}

FB: Flowering buds; F: Flowers; FS: Flowering shoots; Rh: Rhizome; R: Roots; IB: Inner bark; L: Leaves; NA: Not analyzed. 
(A)
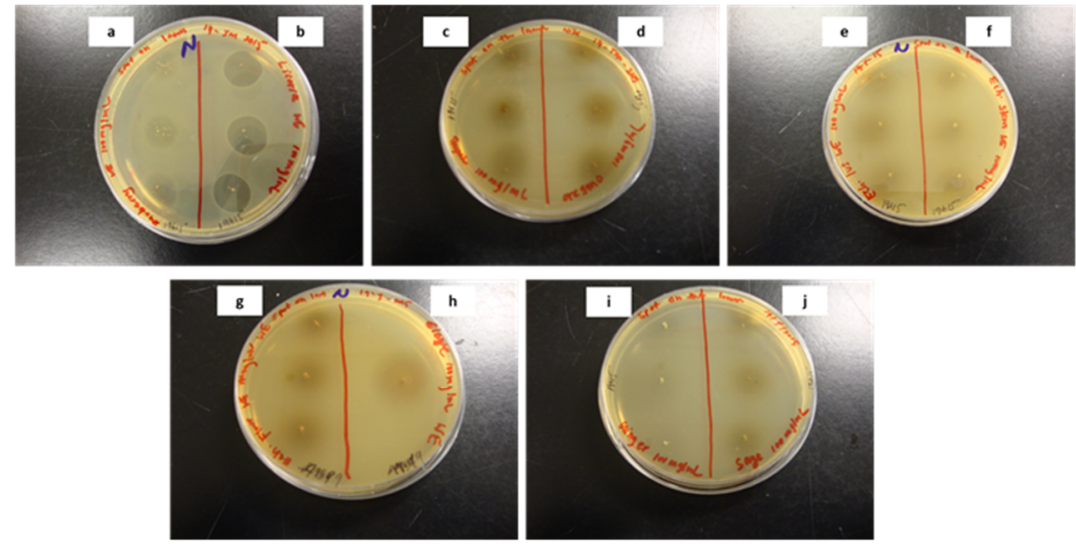

(B)
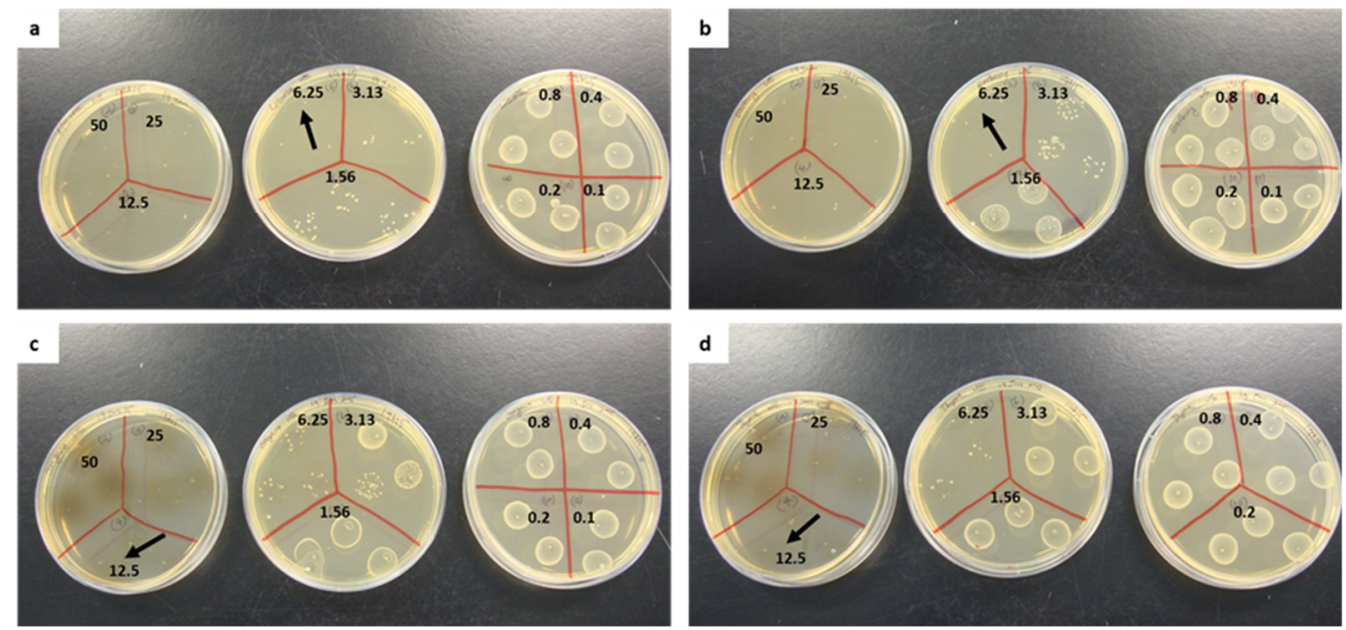

Figure 2. (A) Antibacterial effect of HWIs (100 mg/mL) spotted on brain heart infusion (BHI) agar plates inoculated with the Streptococcus pyogenes ATCC 19615. HWIs: Hot water infusions; a: barberry roots; b: licorice roots; c: thyme flowering shoots; d: oregano flowering shoots; e: echinacea leaves; f: echinacea stems; g: echinacea flowers; h: clove flower buds; i: ginger rhizomes, and j: sage leaves. (B) Sub-culturing for minimum bactericidal concentration on BHI agar plates of four most efficient hot water infusions against S. pyogenes ATCC 19615 followed by the micro-broth dilution assay. a: licorice roots; b: barberry roots; c: oregano flowering shoots; $d$ : thyme flowering shoots.

\subsection{Time to Kill Analysis of HWIs Against S. Pyogenes}

HWIs from licorice roots, barberry roots, thyme flowering shoots, and oregano flowering shoots were selected for time-kill analysis based on their significantly low MIC and MBC values. Time taken to achieve $99.99 \%$ planktonic S. pyogenes kill by the HWIs were assessed, and results are shown in Figure 3. Results showed that licorice HWI exhibits the complete bactericidal effect on S. pyogenes within $12 \mathrm{~h}$ after exposure (Figure 3), whereas barberry, thyme, and oregano required a longer time of $24 \mathrm{~h}$, at their respective MBC. No regrowth was observed after an additional $24 \mathrm{~h}$ incubation. 
a

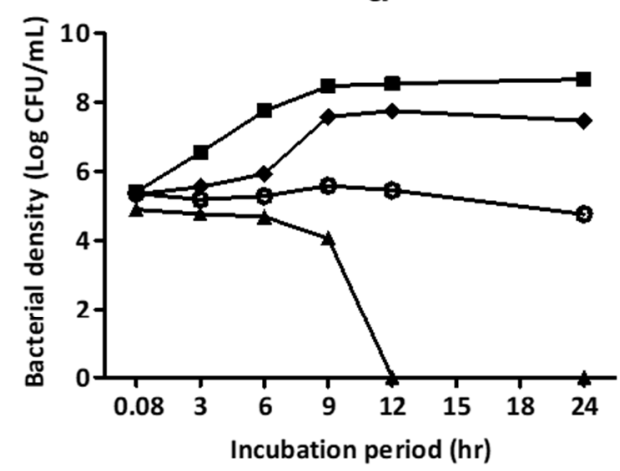

C

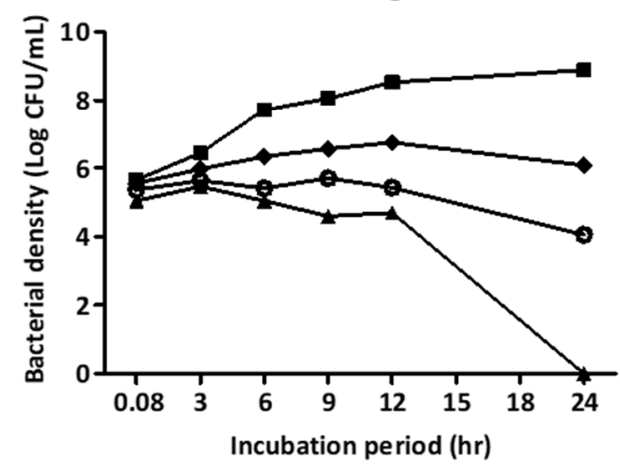

b

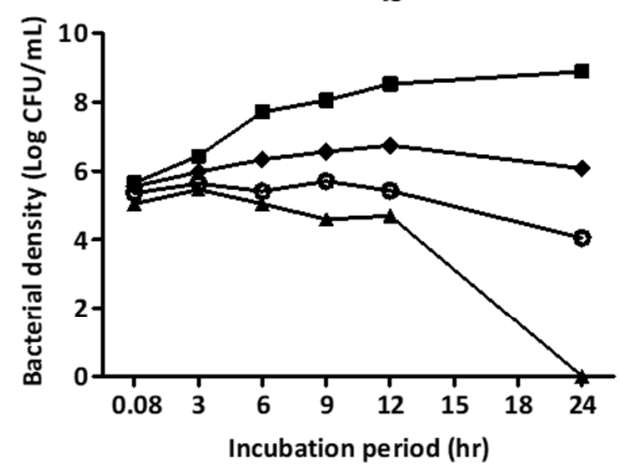

d

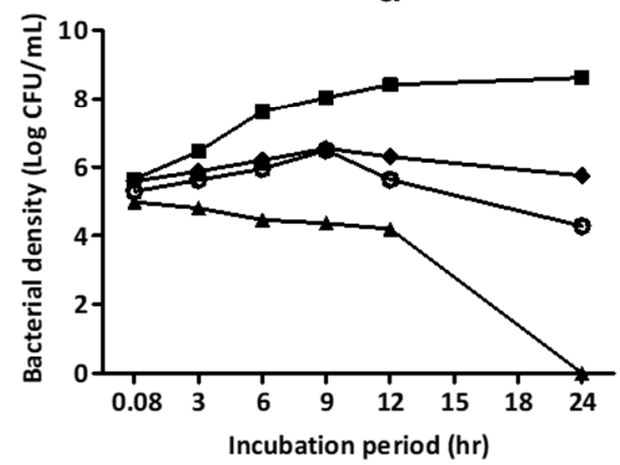

Figure 3. Time-kill curves of the hot water infusions of (a) licorice root, (b) barberry root, (c) oregano flowering shoots, and (d) thyme flowering shoots on the growth of Streptococcus pyogenes ATCC 19615. A viable count was performed for different folds of their respective minimum inhibitory concentrations (MICs) at $0.08,3,6,9,12$, and $24 \mathrm{~h}$ incubation time points. $\boldsymbol{\Delta}=2 \times \mathrm{MIC} ; \bigcirc=\mathrm{MIC} ;=\frac{1}{2} \times \mathrm{MIC} ; \mathbf{\square}=$ BHI media (diluent) control. Each data point represents mean from three independent experiments performed in triplicate.

\subsection{HWIs Possesses Anti-Biofilm Formation Activity}

The HWIs were shown biofilm inhibition activities at the range of 1.56 to $6.25 \mathrm{mg} / \mathrm{mL}$ concentrations where licorice root infusion had the most active antibiofilm activity among the tested HWIs. The inhibition effects of sub-inhibitory concentrations of HWIs of licorice root, barberry root, oregano flowering shoots, and thyme flowering shoots on biofilm formation over $72 \mathrm{~h}$ incubation (Minimum biofilm inhibitory concentration; MBIC) of the three S. pyogenes strains were quantified by MTT staining (Table 3).

Table 3. Minimum biofilm inhibitory concentration (MBIC) against Streptococcus pyogenes strains.

\begin{tabular}{cccc}
\hline \multirow{2}{*}{ Hot Water Infusions } & \multicolumn{3}{c}{ MBIC $(\mathbf{m g} / \mathbf{m L})$} \\
\cline { 2 - 4 } & ATCC 19615 & ATCC 49399 & Clinical \\
\hline Licorice Roots & $1.56(1 \times \mathrm{MIC})$ & $6.25(4 \times \mathrm{MIC})$ & $3.13(2 \times \mathrm{MIC})$ \\
Barberry Root & $6.25(2 \times \mathrm{MIC})$ & $6.25(2 \times \mathrm{MIC})$ & $6.25(2 \times \mathrm{MIC})$ \\
Oregano Flowering shoots & $6.25(2 \times \mathrm{MIC})$ & $6.25(2 \times \mathrm{MIC})$ & $6.25(2 \times \mathrm{MIC})$ \\
Thyme Flowering shoots & $6.25(2 \times \mathrm{MIC})$ & $6.25(2 \times \mathrm{MIC})$ & $6.25(2 \times \mathrm{MIC})$ \\
Penicillin G & $0.0156(2 \times \mathrm{MIC})$ & $0.0625(8 \times \mathrm{MIC})$ & $0.0625(8 \times \mathrm{MIC})$ \\
\hline
\end{tabular}




\subsection{HWIs Cause Morphological Changes of S. pyogenes Biofilms}

The inhibition of biofilm was significantly effective, along with four HWIs when compared to controls, as shown in Figure 4. Mainly, biofilm reduction by $1 / 2 \times$ MIC and MIC values of HWIs was about $87.4 \%$ and $99.1 \%$ for licorice root, $36.6 \%$ and $97.0 \%$ for barberry root, $37.9 \%$ and $95.8 \%$ for oregano, and $35.3 \%$ and $94.0 \%$ for thyme flowering shoot, respectively. Surface structure and morphology changes of biofilms formed with or without HWIs treatment at their sub-inhibitory MIBC, S. pyogenes ATCC 19615 are shown in Figure 5. The SEM analysis revealed that the HWIs cause noticeable cellular lysis and morphological alterations compared to untreated cells. Biofilms of untreated control showed a typical multi-layer bacterial colony growth while a significant reduction in microcolonies was observed in HWI-treated samples. Even at sub-inhibitory concentrations, penicillin $\mathrm{G}$ eradicated biofilm leaving a few of dead cell debris. Interestingly, HWIs of thyme and oregano were also showed significant destruction of biofilm by leaving either a few bacteria or cell debris. Dead cell debris resulted from substantial biofilm inhibition by barberry root HWI treatment resulting in a cluster, as shown in Figure 5. However, active disruption morphologies of cells such as ruptured shape were observed. Therefore, our findings provide evidence that HWIs has an intense antimicrobial action against S. pyogenes biofilm formation.
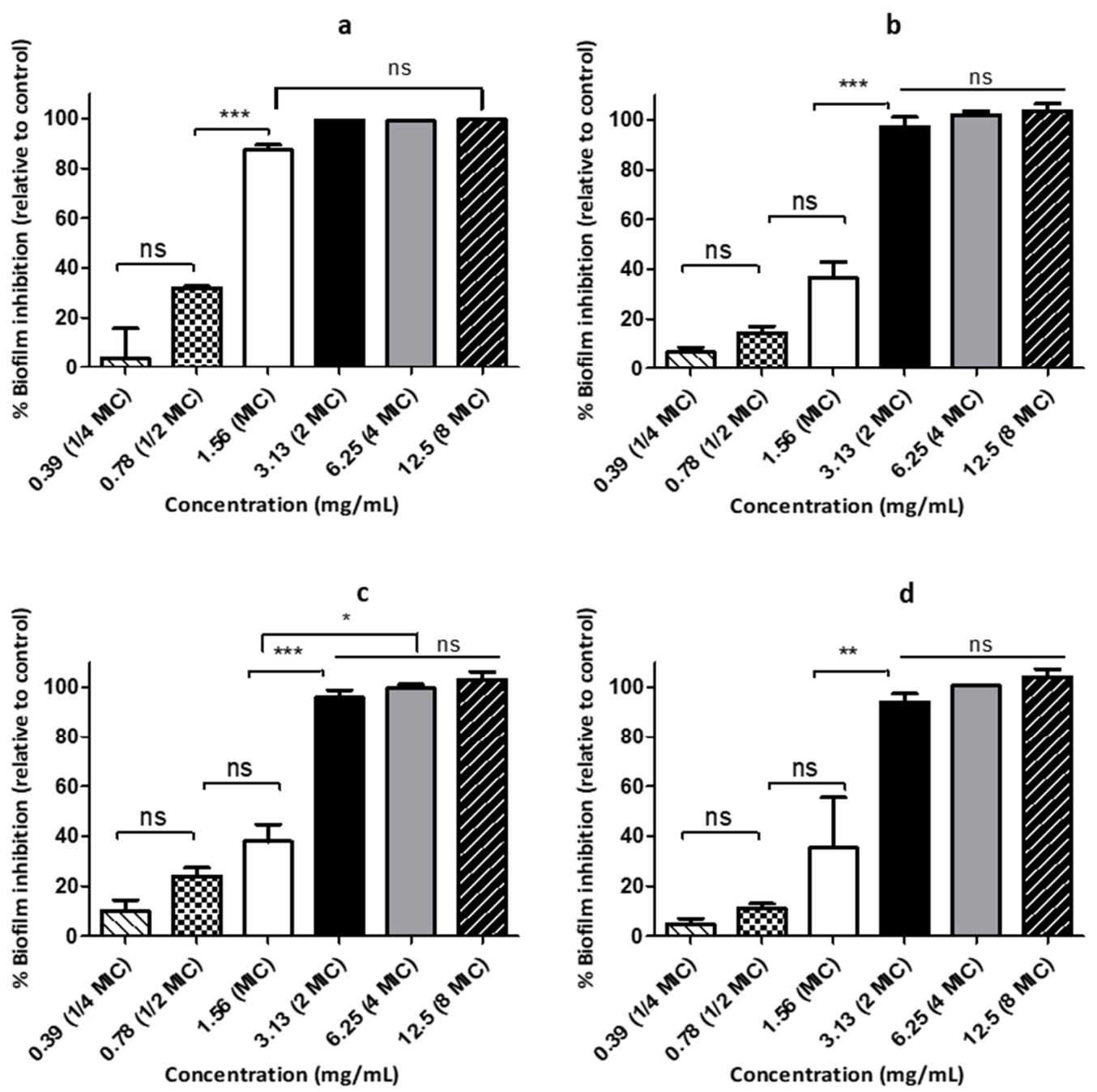

Figure 4. Inhibition of biofilm formation of Streptococcus pyogenes 19615 by hot water infusions at various concentrations. (a) licorice roots, (b) barberry roots, (c) oregano flowering shoots, and (d) thyme flowering shoots. Each data point represents mean \pm SD from three independent experiments performed in triplicate. 


\section{Bacteria/diluent control \\ (BHI media)}

Licorice root

HWI

Oregano

flowering shoots

HWI

\section{Thyme \\ flowering shoots HWI}

\section{Barberry root HWI}

Penicillin G
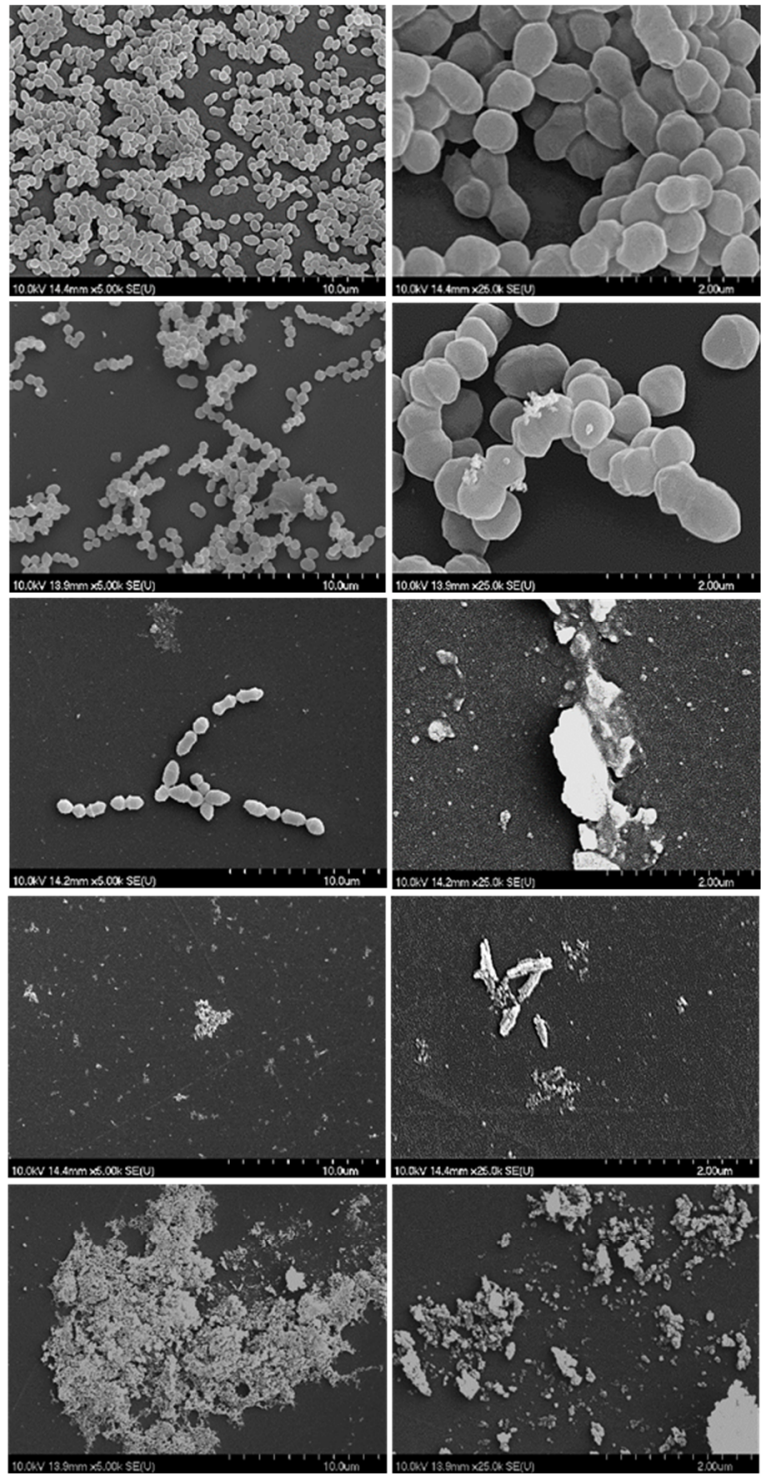

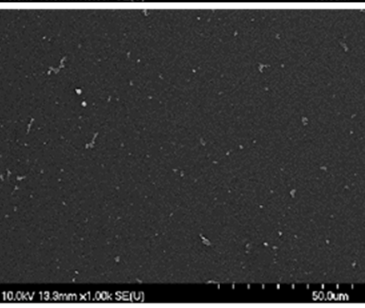

$\times 5000$

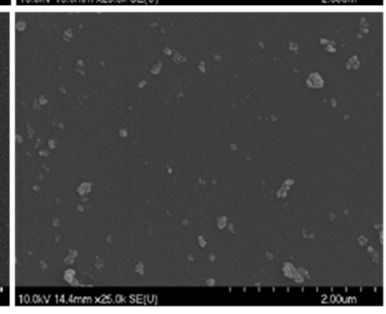

$\times 25000$

Figure 5. Scanning electron micrographs of biofilms of Streptococcus pyogenes formed on the microplate surface with the presence of hot water infusions of licorice roots, oregano flowering shoots, thyme flowering shoots, barberry root and penicillin $\mathrm{G}$ at their sub-inhibitory concentrations. HWI, hot water infusion.

\section{Discussion}

Herbaceous plants are a source of complementary and alternative remedies to conventional medications in treating several bacterial infectious diseases, including streptococcal pharyngitis (strep throat). Previous studies have demonstrated that numerous herbal extracts could act as antibacterial agents against S. pyogenes [10,34-38]. In the present study, we focused on 13 HWIs, known to Canadian traditional and indigenous healers who used them against sore throat. The goal is to identify herbal 
plants as sources for specialty herbal tea to use in the management of streptococcal pharyngitis. Furthermore, we identified the major bioactive components in those HWIs that may contribute to their overall antimicrobial activities against $S$. pyogenes.

Spices and herbs (flavor foods) comprise a large number of phytochemicals [39], which have been revealed to possess antimicrobial properties. For example, anti-S. pyogenes ability of phenolic compounds [40,41], flavonoids [35], alkaloids [42], terpenoids [43], and tannins [35] have been reported. Qualitative UPLC analysis in the present study for HWI revealed the presence of polyphenols, flavonoids, alkaloids, terpenoids, steroids, and tannins. The phytochemical constituents of the different plants, as well as different parts of the same plant, showed phytochemical diversity, which partially explains the different antimicrobial potential established as a range of MIC and MBC values.

When comparing MIC and MBC values of the present study, licorice root, barberry root, oregano flowering shoot, and thyme flowering shoot infusions were identified as the most efficient HWIs. Similar antimicrobial potential of various varieties of thyme and oregano from different countries was also reported against Streptococcus species $[43,44]$. The Anti-bacterial efficacy of licorice root infusion was the most active extracts which showed the lowest MIC. Although HWIs of barberry, thyme, and oregano showed a concentration- and time-dependent bacteriostatic effect, a significant bactericidal effect was observed in licorice root infusion within $12 \mathrm{~h}$ of exposure at the concentration of $2 \times$ MIC. The existence of antibacterial activities could be due to one or a few of phytochemicals specific to particular plant species or a particular part of a plant used. The chemical characterization of licorice infusion suggested the presence of specific phytochemicals such as glycyrrhizin, glabridin, naringenin, asparagine, and 5-methoxyhydnocarpin. Previous studies have also demonstrated that isoflavonoid compounds, such as glabridin, glycyrrhizin, glabriol, and hispaglabridin in the extracts purified from licorice roots, can act as bactericidal agents against various microorganisms [45].

Biofilm formation in S. pyogenes infections is one of the significant defensive mechanisms during pharyngitis infections where microbial cells tightly arranged and covered with extra polymeric substances [46,47]. Usually, biofilms make bacteria more resistant to antibiotics than their planktonic cells. Several other studies have shown that extractions or infusions from medicinal plants inhibit the biofilm formation in different bacteria, including S. pyogenes [41,48,49]. Our findings suggest that these HWIs of licorice roots, barberry roots, oregano, and thyme flowering shoots could be used against drug resistant-S. pyogenes. The present study investigated morphological changes such as structural alterations of $S$. pyogenes after exposure to the effective infusion treatments at their sub-MIBCs. The destruction of bacterial biofilms and cells shown in the SEM images are compatible with biofilm quantification findings of the MTT assay. Similar SEM observations against $S$. pyogenes have been reported $[40,50]$.

Due to the recognition of significant healing power in traditional medicine systems, herbal medicines from indigenous pharmacopeia are being used as home remedies. On the other hand, public perception of using functional foods as biomedicines has begun to expand, especially in the Western world. Therefore, opportunities exist for innovation of efficacious, safe, and convenient herbal products as functional foods/biomedicines such as herbal teas and herbal tonics. However, some of the pharmacologically active compounds in herbs may cause side effects; thus, proper ethnomedical verification of efficacy and safety is required. On the other hand, no universal regulatory system ensures the efficacy and safety of plant remedies. Moreover, different countries have their policies and classification for natural health products. For example, herbal teas are categorized under "herb and plant-based remedies" in the Licensed Natural Health Products Database (LNHPD) in Canada and trade as an over-the-counter (OTC) product according to the report by consumer health product Canada [51], while herbal teas are traded as a dietary supplement in the United States. Therefore, extensive evidence for the in vitro, in vivo, or clinical efficacies, as well as pharmacological mechanisms of their phytochemical constituents, is necessary for the new product development.

Destruction of the cell wall, loss of cell membrane integrity due to disruption of phospholipid bilayer and inhibition of cell wall, membrane, protein, and DNA/RNA synthesis are considered as 
potential mechanisms of phytochemicals on their antibacterial and antibiofilm activities. However, since these HWIs contain a large number of different phytochemicals they may responsible for these activities through different mechanisms insole or combine. However, the present study does not have sufficient evidence to conclude the exact mechanism/s of these herbal extracts. Among the four most efficacious extracts identified, only licorice HWI shows moderately quick (12 h) bactericidal effect at its MBC value. The SEM images show clear cell destructions by the four HWIs when the bacterial cultures were exposed to longer period at their sub-inhibitory concentrations. Leakage of intracellular components followed by the loss of integrity of phospholipid bilayer and ultimately leading to cell death may be the reason for observed lesser bacterial density and deformed cells/debris. Licorice root, sage leaves, oregano, and thyme HWIs show bacteriostatic effects at lower concentrations, which suggest they may not have immediate cell wall or membrane destruction effect. The chemical structure of individual antimicrobial phytochemicals and their abundance in the efficacious HWIs are important for their mechanisms of action. Licorice root extract contains flavonoids, isoflavones, saponins, and coumarins, which may regulate the expression of genes responsible for bacterial virulence of streptococcus species have been reported [52,53]. Different species of thyme and oregano were reported to possess some antimicrobial activities [44]. Both of plant leaves or young shoots are used in various food preparations as flavor enhancers as well as in herbal remedies. Although the modes of action of the extracts are not clearly recognized, it may be due to the major bioactive compounds, including thymol, terpenes, eugenol, flavones, glycosides of phenolic monoterpenoids, and aliphatic alcohols, among others [44,54].

Herbal teas provide relief for pharyngeal inflammation in patients with streptococcal pharyngitis. Anti-inflammatory activities of herbal extracts and infusions have been shown by several authors previously $[55,56]$. Our recently published data on anti-inflammatory properties of these extracts have proven the ability of all four efficacious HWIs for suppression of pro-inflammatory cytokines released from inflamed human tonsil epithelial cells (HTonEpiCs) induced by antigens (lipoteichoic acid and peptidoglycan) of S. pyogenes [8]. Following the herbal treatment, production of IL-8, hBD-2, ENA-78, and CGP-2 was suppressed in HTonEpiCs. However, to use them as biomedicine such as herbal tea with antibacterial and anti-inflammatory compounds, the suppressive effect of pro-inflammatory cytokines production by HWIs is expected only to happen in inflamed cells without affecting to the healthy pharynx epithelium cells. Therefore, we have previously performed cell viability assay to assess the cytotoxicity of these extracts on HTonEpiCs and found that all HWIs showed no cytotoxicity to the HTonEpiCs in vitro [8]. Therefore, use of these HWIs seems to be safer but further validations using in vivo models are required. The dry weight-based extraction yield of licorice, barberry, oregano, and thyme were $19.5 \% 6.0 \%, 8.2 \%$, and $18.6 \%$, respectively [ 8 ] which could be further enhanced by the improved technology such as subcritical water extraction.

Moreover, the water-based extraction process used in this study is acceptable for functional beverage applications as no chemical was used in the preparation and allows incorporation of the extracts in natural health products without concern of potential toxic solvent residuals [57]. Additionally, the preparation of infusions is simple, fast, and economical, and their applicability in commercial product development is straightforward. Therefore, it is possible that the use of non-toxic concentrations of licorice, barberry, thyme, or oregano infusions to develop into functional beverages, biomedicine, and natural health products for the management of streptococcal pharyngitis.

\section{Conclusions}

We report the inhibitory effect on the growth and formation of biofilm of S. pyogenes by phytochemical-rich HWIs of selected Canadian traditional herbal plants. The water-based extraction process is economical, environment- and consumer-friendly as well as allows the incorporation of the extracts in functional foods without concern of solvent residuals. Therefore, we conclude that HWIs of licorice, barberry, thyme, or oregano at their non-toxic concentrations as safe and efficient symptomatic treatments for the management of discomfort conditions associated with strep throat of 
streptococcal pharyngitis patients. Potential mechanisms of antibacterial and antibiofilm properties of these efficacious infusions may be due to the direct destruction of cell wall/membrane, inhibition of biosynthesis of cell wall/membrane, and inhibition of protein synthesis involved growth, adherence, and biofilm formation. However, further investigations are required to determine the impact of HWIs on cell wall/membrane leakage and specific gene expression to reveal the mechanisms of cell disruption, adhesion, and biofilm formation by presumed phytochemicals.

Supplementary Materials: The following are available online at http://www.mdpi.com/2227-9059/7/3/63/s1.

Author Contributions: H.P.V.R. (principal investigator) and N.M.W. designed the experiments; N.M.W. performed the sample collection, sample preparation, conducted the experiments, and data analysis. Both authors wrote the manuscript.

Funding: This research was funded by the Collaborative Research and Development Grant program (CRDPJ 448052) of the Natural Sciences and Engineering Research Council (NSERC) and Canada and Island Abbey Foods, Charlottetown, PEI, Canada.

Acknowledgments: The authors acknowledge the assistance of Jeff Morton (Department of Plant, Food, and Environmental Sciences, Faculty of Agriculture, Dalhousie University) for sample collection and authentication, Ryan Gibbs and Cory Murphy (Canadian Food Inspection Agency, Dartmouth, NS, Canada) for UPLC-ESI-MS/MS analysis, and Ross J. Davidson (Director of Bacteriology, Division of Microbiology, Queen Elizabeth II Health Sciences Centre, Halifax, NS, Canada) for providing a bacterial clinical isolate as a gift.

Conflicts of Interest: The authors declare no conflict of interest. The funders had no role in the design of the study; in the collection, analyses, or interpretation of data; in the writing of the manuscript, or in the decision to publish the results.

\section{References}

1. Cirilli, A.R. Emergency evaluation and management of the sore throat. Emerg. Med. Clin. N. Am. 2013, 31, 501-515. [CrossRef] [PubMed]

2. Shaikh, N.; Leonard, E.; Martin, J.M. Prevalence of streptococcal pharyngitis and streptococcal carriage in children: A meta-analysis. Pediatrics 2010, 126, e557-e564. [CrossRef] [PubMed]

3. Moreira, D.d.L.; Teixeira, S.S.; Monteiro, M.H.D.; De-Oliveira, A.C.A.X.; Paumgartten, F.J.R. Traditional use and safety of herbal medicines1. Rev. Bras. De Farmacogn. 2014, 24, 248-257. [CrossRef]

4. Oyebode, O.; Kandala, N.-B.; Chilton, P.J.; Lilford, R.J. Use of traditional medicine in middle-income countries: A WHO-SAGE study. Health Policy Plan. 2016, 31, 984-991. [CrossRef] [PubMed]

5. Rashrash, M.; Schommer, J.C.; Brown, L.M. Prevalence and predictors of herbal medicine use among adults in the United States. J. Patient Exp. 2017, 4, 108-113. [CrossRef] [PubMed]

6. Moerman, D.E. An analysis of the food plants and drug plants of native North America. J. Ethnopharmacol. 1996, 52, 1-22. [CrossRef]

7. Nafiu, M.O.; Hamid, A.A.; Muritala, H.F.; Adeyemi, S.B. Chapter 7-Preparation, standardization, and quality control of medicinal plants in Africa. In Medicinal Spices and Vegetables from Africa; Kuete, V., Ed.; Academic Press: Cambridge, MA, USA, 2017; pp. 171-204.

8. Wijesundara, N.M.; Sekhon-Loodu, S.; Rupasinghe, H.P.V. Phytochemical-rich medicinal plant extracts suppress bacterial antigens-induced inflammation in human tonsil epithelial cells. PeerJ 2017, 5, e3469. [CrossRef] [PubMed]

9. Wijesundara, N.M.; Rupasinghe, H.P.V. Bactericidal and anti-biofilm activity of ethanol extracts derived from selected medicinal plants against Streptococcus pyogenes. Molecules 2019, 24. [CrossRef] [PubMed]

10. Wijesundara, N.M.; Rupasinghe, H.P.V. Essential oils from Origanum vulgare and Salvia officinalis exhibit antibacterial and anti-biofilm activities against Streptococcus pyogenes. Microb. Pathog. 2018, 117, 118-127. [CrossRef] [PubMed]

11. CLSI. Methods for Dilution Antimicrobial Susceptibility Tests for Bacteria that Grow Aerobically: Approved Standard. Available online: https://simpleshowoflove.weebly.com/uploads/1/4/0/7/14073276/agar_dilution_ assay.pdf (accessed on 23 August 2019).

12. Deepak, P.; Prativa, B.; Suri, K.A. Isolation of berberine from Berberis vulgaris Linn. and standardization of aqueous extract by RP-HPLC. Int. J. Herb. Med. 2013, 1, 106-111. 
13. Yun, S.M.; Lee, M.H.; Lee, K.J.; Ku, H.O.; Son, S.W.; Joo, Y.S. Quantitative analysis of eugenol in clove extract by a validated HPLC method. J. AOAC Int. 2010, 93, 1806-1810. [PubMed]

14. Brito, R.E.; González-Rodríguez, J.; Montoya, M.R.; Rodríguez Mellado, J.M. Comparison of the volatile antioxidant contents in the aqueous and methanolic extracts of a set of commercial spices and condiments. Eur. Food Res. Technol. 2017, 243, 1439-1445. [CrossRef]

15. Sahin, S.; Eulenburg, V.; Heinlein, A.; Villmann, C.; Pischetsrieder, M. Identification of eugenol as the major determinant of GABAA-receptor activation by aqueous Syzygium aromaticum L. (clove buds) extract. J. Funct. Foods 2017, 37, 641-649. [CrossRef]

16. Erenler, R.; Telci, I.; Ulutas, M.; Demirtas, I.; Gul, F.; Elmastas, M.; Kayir, O. Chemical constituents, quantitative analysis and antioxidant activities of Echinacea purpurea (L.) Moench and Echinacea pallida (Nutt.) Nutt. J. Food Biochem. 2015, 39, 622-630. [CrossRef]

17. Brown, P.N.; Chan, M.; Paley, L.; Betz, J.M. Determination of major phenolic compounds in Echinacea spp. raw materials and finished products by high-performance liquid chromatography with ultraviolet detection: Single-laboratory validation matrix extension. J. AOAC Int. 2011, 94, 1400-1410. [CrossRef] [PubMed]

18. Mølgaard, P.; Johnsen, S.; Christensen, P.; Cornett, C. HPLC method validated for the simultaneous analysis of cichoric acid and alkamides in Echinacea purpurea plants and products. J. Agric. Food Chem. 2003, 51, 6922-6933. [CrossRef] [PubMed]

19. Senica, M.; Mlinsek, G.; Veberic, R.; Mikulic-Petkovsek, M. Which plant part of purple coneflower (Echinacea purpurea (L.) Moench) should be used for tea and which for tincture? J. Med. Food 2018, 22, 102-108. [CrossRef]

20. Nile, S.H.; Park, S.W. Chromatographic analysis, antioxidant, anti-inflammatory, and xanthine oxidase inhibitory activities of ginger extracts and its reference compounds. Ind. Crop. Prod. 2015, 70, 238-244. [CrossRef]

21. Krüger, S.; Bergin, A.; Morlock, G.E. Effect-directed analysis of ginger (Zingiber officinale) and its food products, and quantification of bioactive compounds via high-performance thin-layer chromatography and mass spectrometry. Food Chem. 2018, 243, 258-268. [CrossRef]

22. Komes, D.; Belščak-Cvitanović, A.; Jurić, S.; Bušić, A.; Vojvodić, A.; Durgo, K. Consumer acceptability of liuorice root (Glycyrrhiza glabra L.) as an alternative sweetener and correlation with its bioactive content and biological activity. Int. J. Food Sci. Nutr. 2016, 67, 53-66. [CrossRef]

23. Zhou, J.X.; Braun, M.S.; Wetterauer, P.; Wetterauer, B.; Wink, M. Antioxidant, cytotoxic, and antimicrobial activities of Glycyrrhiza glabra L., Paeonia lactiflora Pall., and Eriobotrya japonica (Thunb.) Lindl. extracts. Medicines 2019, 6, 43. [CrossRef] [PubMed]

24. Méabed, E.M.H.; El- Sayed, N.M.; Abou-Sreea, A.I.B.; Roby, M.H.H. Chemical analysis of aqueous extracts of Origanum majorana and Foeniculum vulgare and their efficacy on Blastocystis spp. cysts. Phytomedicine 2018, 43, 158-163. [CrossRef] [PubMed]

25. Roby, M.H.H.; Sarhan, M.A.; Selim, K.A.-H.; Khalel, K.I. Evaluation of antioxidant activity, total phenols and phenolic compounds in thyme (Thymus vulgaris L.), sage (Salvia officinalis L.), and marjoram (Origanum majorana L.) extracts. Ind. Crop. Prod. 2013, 43, 827-831. [CrossRef]

26. Savarese, M.; De Marco, E.; Sacchi, R. Characterization of phenolic extracts from olives (Olea europaea cv. Pisciottana) by electrospray ionization mass spectrometry. Food Chem. 2007, 105, 761-770. [CrossRef]

27. Silva, S.; Gomes, L.; Leitão, F.; Coelho, A.; Boas, L. Phenolic compounds and antioxidant activity of Olea europaea L. fruits and leaves. Food Sci. Technol. Int. 2006, 12, 385-395. [CrossRef]

28. Quirantes-Piné, R.; Lozano-Sánchez, J.; Herrero, M.; Ibáñez, E.; Segura-Carretero, A.; Fernández-Gutiérrez, A. HPLC-ESI-QTOF-MS as a powerful analytical tool for characterising phenolic compounds in olive-leaf extracts. Phytochem. Anal. 2013, 24, 213-223. [CrossRef] [PubMed]

29. Boukhris, M.; Simmonds, M.S.; Sayadi, S.; Bouaziz, M. Chemical composition and biological activities of polar extracts and essential oil of rose-scented geranium, Pelargonium graveolens. Phytother Res. 2013, 27, 1206-1213. [CrossRef]

30. Martins, N.; Barros, L.; Santos-Buelga, C.; Henriques, M.; Silva, S.; Ferreira, I.C.F.R. Evaluation of bioactive properties and phenolic compounds in different extracts prepared from Salvia officinalis L. Food Chem. 2015, 170, 378-385. [CrossRef]

31. Fecka, I.; Turek, S. Determination of water-soluble polyphenolic compounds in commercial herbal teas from lamiaceae: Peppermint, melissa, and sage. J. Agric. Food Chem. 2007, 55, 10908-10917. [CrossRef] 
32. Barsett, H.; Smestad Paulsen, B. Separation, isolation and characterization of acidic polysaccharides from the inner bark of Ulmus glabra Huds. Carbohydr. Polym. 1992, 17, 137-144. [CrossRef]

33. Fecka, I.; Turek, S. Determination of polyphenolic compounds in commercial herbal drugs and spices from Lamiaceae: Thyme, wild thyme and sweet marjoram by chromatographic techniques. Food Chem. 2008, 108, 1039-1053. [CrossRef] [PubMed]

34. Adil, M.; Khan, R.; Rupasinghe, H.P.V. Application of medicinal plants as a source for therapeutic agents against Streptococcus pyogenes infections. Curr. Drug Metab. 2018, 19, 695-703. [CrossRef] [PubMed]

35. Mpala, L.; Chikowe, G.; Cock, I.E. Brachychiton rupestris (T.Mitch. ex Lindl.) K. Schum. Extracts Inhibit the Growth of Streptococcus pyogenes. Pharmacogn. Commun. 2019, 9, 27-33. [CrossRef]

36. Wright, M.H.; Arnold, M.S.J.; Lee, C.J.; Courtney, R.; Greene, A.C.; Cock, I.E. Qualitative phytochemical analysis and antibacterial activity evaluation of indian Terminalia spp. against the pharyngitis causing pathogen Streptococcus pyogenes. Pharmacogn. Commun. 2016, 6, 85-92. [CrossRef]

37. Wajima, T.; Kinugawa, R.; Yamada, T.; Ikoshi, H.; Noguchi, N. Panax Notoginseng extract possesses significant antibacterial activity against pathogenic Streptococci. Pharmacology 2019, 103, 221-227. [CrossRef]

38. Mehreen, A.; Waheed, M.; Liaqat, I.; Arshad, N. Phytochemical, antimicrobial, and toxicological evaluation of traditional herbs used to treat sore throat. Biomed. Res. Int. 2016, 2016, 8503426. [CrossRef] [PubMed]

39. Cowan, M.M. Plant products as antimicrobial agents. Clin. Microbiol. Rev. 1999, 12, 564-582. [CrossRef]

40. Macé, S.; Truelstrup Hansen, L.; Rupasinghe, H.P.V. Anti-bacterial activity of phenolic compounds against Streptococcus pyogenes. Medicines 2017, 4, 25. [CrossRef]

41. Lemos, A.S.O.; Campos, L.M.; Melo, L.; Guedes, M.C.M.R.; Oliveira, L.G.; Silva, T.P.; Melo, R.C.N.; Rocha, V.N.; Aguiar, J.A.K.; Apolônio, A.C.M.; et al. Antibacterial and antibiofilm activities of psychorubrin, a pyranonaphthoquinone isolated From Mitracarpus frigidus (Rubiaceae). Front. Microbiol. 2018, 9, 724. [CrossRef]

42. Sara, G.Y.; Dauda, S.; Emmanuel, A.; Bhutto, Y.Y.; Joseph, I. Phytochemical screening and antimicrobial activity of leaf and stem-bark aqueous extracts of Diospyros mespiliformis. Int. J. Biochem. Res. Rev. 2018, 22, 1-8. [CrossRef]

43. Sfeir, J.; Lefrancois, C.; Baudoux, D.; Derbre, S.; Licznar, P. In vitro antibacterial activity of essential oils against Streptococcus pyogenes. Evid.-Based Complement. Altern. Med. 2013, 2013, 9. [CrossRef] [PubMed]

44. Fournomiti, M.; Kimbaris, A.; Mantzourani, I.; Plessas, S.; Theodoridou, I.; Papaemmanouil, V.; Kapsiotis, I.; Panopoulou, M.; Stavropoulou, E.; Bezirtzoglou, E.E.; et al. Antimicrobial activity of essential oils of cultivated oregano (Origanum vulgare), sage (Salvia officinalis), and thyme (Thymus vulgaris) against clinical isolates of Escherichia coli, Klebsiella oxytoca, and Klebsiella pneumoniae. Microb. Ecol. Health Dis. 2015, 26, 23289. [CrossRef] [PubMed]

45. Fu, Y.; Chen, J.; Li, Y.J.; Zheng, Y.F.; Li, P. Antioxidant and anti-inflammatory activities of six flavonoids separated from licorice. Food Chem. 2013, 141, 1063-1071. [CrossRef] [PubMed]

46. Ogawa, T.; Terao, Y.; Okuni, H.; Ninomiya, K.; Sakata, H.; Ikebe, K.; Maeda, Y.; Kawabata, S. Biofilm formation or internalization into epithelial cells enable Streptococcus pyogenes to evade antibiotic eradication in patients with pharyngitis. Microb. Pathog. 2011, 51, 58-68. [CrossRef] [PubMed]

47. Post, J.C.; Stoodley, P.; Hall-Stoodley, L.; Ehrlich, G.D. The role of biofilms in otolaryngologic infections. Curr. Opin. Otolaryngol. Head Neck Surg. 2004, 12, 185-190. [CrossRef] [PubMed]

48. Darsini, D.T.P.; Srinivasan, P.; Guna, G.; Manimekalai, K.; Dineshbabu, J. In vitro anti-biofilm activity of Piper longum and Piper nigrum against clinical isolates of S. pyogenes isolated from pharyngitis patients. Int. J. Pharm. 2015, 6, 122-132. [CrossRef]

49. Abachi, S.; Lee, S.; Rupasinghe, H.P.V. Molecular mechanisms of inhibition of Streptococcus species by phytochemicals. Molecules 2016, 21, 215. [CrossRef] [PubMed]

50. Fiedler, T.; Riani, C.; Koczan, D.; Standar, K.; Kreikemeyer, B.; Podbielski, A. Protective mechanisms of respiratory tract Streptococci against Streptococcus pyogenes biofilm formation and epithelial cell infection. Appl. Environ. Microbiol. 2013, 79, 1265-1276. [CrossRef]

51. North American Trends in the Consumer Health Product Industry. Available online: https://www.chpcanada. ca/wp-system/uploads/2017/12/CHPC-CHPA-RCC-Submission-2016-FINAL.pdf (accessed on 23 August 2019).

52. Wang, L.; Yang, R.; Yuan, B.; Liu, Y.; Liu, C. The antiviral and antimicrobial activities of licorice, a widely-used Chinese herb. Acta Pharm. Sin. B 2015, 5, 310-315. [CrossRef] 
53. Ahn, S.-J.; Cho, E.-J.; Kim, H.-J.; Park, S.-N.; Lim, Y.-K.; Kook, J.-K. The antimicrobial effects of deglycyrrhizinated licorice root extract on Streptococcus mutans UA159 in both planktonic and biofilm cultures. Anaerobe 2012, 18, 590-596. [CrossRef]

54. Nzeako, B.C.; Al-Kharousi, Z.S.; Al-Mahrooqui, Z. Antimicrobial activities of clove and thyme extracts. Sultan. Qaboos. Univ. Med. J. 2006, 6, 33-39. [PubMed]

55. Kogiannou, D.A.A.; Kalogeropoulos, N.; Kefalas, P.; Polissiou, M.G.; Kaliora, A.C. Herbal infusions; their phenolic profile, antioxidant and anti-inflammatory effects in HT29 and PC3 cells. Food Chem. Toxicol. 2013, 61, 152-159. [CrossRef] [PubMed]

56. Sekita, Y.; Murakami, K.; Yumoto, H.; Hirao, K.; Amoh, T.; Fujiwara, N.; Hirota, K.; Fujii, H.; Matsuo, T.; Miyake, Y.; et al. Antibiofilm and anti-inflammatory activities of Houttuynia cordata decoction for oral care. Evid.-Based Complement. Altern. Med. 2017, 2017. [CrossRef] [PubMed]

57. Wang, L.; Weller, C.L. Recent advances in extraction of nutraceuticals from plants. Trends Food Sci. Technol. 2006, 17, 300-312. [CrossRef]

(C) 2019 by the authors. Licensee MDPI, Basel, Switzerland. This article is an open access article distributed under the terms and conditions of the Creative Commons Attribution (CC BY) license (http://creativecommons.org/licenses/by/4.0/). 